\title{
74-George Orwell'in '1984' romanının iki Türkçe çevirisindeki eğretilemeli ifadelerin norm ve eşdeğerlik temelli betimleyici bir incelemesi
}

Zafer SARI 1

Ayşe Selmin SÖYLEMEZ²

APA: Sarı, Z. \& Söylemez, A. S. (2022). George Orwell'in '1984' romanının iki Türkçe çevirisindeki eğretilemeli ifadelerin norm ve eșdeğerlik temelli betimleyici bir incelemesi. RumeliDE Dil ve Edebiyat Araştırmaları Dergisi, (26), 1191-1207. DOI: 10.2900o/rumelide.1074534.

\section{$\ddot{\mathbf{O} z}$}

Çalışmanın amacı, George Orwell tarafından yazılan “1984” adlı romandaki eğretilemeli ifadelerin iki farklı Türkçe çevirisini Gideon Toury ile Eugene A. Nida’nın Çeviri Kuramları ışığında karşılaştırmalı ve betimleyici bir şekilde incelemektir. Bu bağlamda çalışma, Orwell’in romanında yer verdiği eğretilemeli kullanımların çevirmenler tarafından Türkçeye ve Türk kültürüne nasıl aktarıldığını tespit edebilmeyi amaçlamaktadır. Bu amaç doğrultusunda üç bölümden oluşan kaynak metnin her bölümünden, içerisinde eğretilemeli ifade bulunan üçer tane olmak üzere toplamda dokuz adet metin birimi seçilmiş ve Toury'nin Normlar Kuramı ile Nida'nın Biçimsel ve Devingen Eşdeğerlik Kuramı çerçevesinde çözümlenmiştir. Çalışmada kaynak metin olarak asıl metnin Penguen Kitapları yayınevince 2008 yılında basılan nüshasından; erek metinler olarak da asıl metnin Türkçedeki ilk çevirisi olan 1958 - V. Turhan ve S. Tonguç çevirisi ile Türk okuyucuları arasında en çok rağbet gören 2010 - Celâl Üster çevirisinden yararlanılmıştır. Çalışma, nitel araştırma yöntemlerinden doküman analizi yöntemiyle gerçekleştirilmiştir. Çalışmanın sonucunda elde edilen bulgular değerlendirildiğinde erek metin çevirmenlerinin iki farklı çeviri yaklaşımı benimsedikleri anlaşılmaktadır. Birinci erek metin çevirmenleri Turhan ve Tonguç'un eğretilemeli ifadeleri çevirirken kimi zaman kaynak metnin oluşturulduğu kültürel normlara kimi zaman da erek dil ve kültürün normlar dizgesine sadık kaldıkları görülmektedir. Dolayısıyla eğretileme çevirileri bağlamında hem "yeterli" hem de "kabul edilebilir" nitelikte çeviriler ortaya koydukları söylenebilir. Bu bağlamda da kaynak metinle çeviri metinleri arasında bazı durumlarda "biçimsel”, bazı durumlarda da "devingen eşdeğerliğin" sağlandığı savunulabilir. Ayrıca çevirmenlerin eğretileme çevirilerinde atlamalara başvurdukları gözlemlendiğinden kısa ve öz bir erek metin oluşturmayı amaçladıkları söylenebilir. İkinci erek metin çevirmeni Üster ise eğretilemeli ifadeleri erek dil ve kültürün normlarına bağlı kalarak çevirme eğilimi göstermiştir. Bu açıdan eğretilemeli ifadelerin çevirisinde "kabul edilebilir" nitelikte bir çeviri yaklaşımı benimsediği ileri sürülebilir. Bu durumda kaynak metinden bazı sapmaların yaşanması da beklenen bir sonuçtur. Kaynak metnin okuyucusunda yarattığı etkinin aynısını kendi okuyucusunda da yaratmayı hedeflediği düşünüldüğünden “devingen eşdeğerliği” sağladı̆̆ı savunulabilir.

Anahtar kelimeler: Çeviri analizi, eğretileme çevirisi, kültürel normlar, biçimsel eşdeğerlik, devingen eşdeğerlik

Öğr. Gör., Ankara Hacı Bayram Veli Üniversitesi, Yabancı Diller Yüksekokulu (Ankara, Türkiye), zafersari26@hotmail.com, ORCID ID: 00oo-0003-2318-4941 [Araştırma makalesi, Makale kayıt tarihi: 18.01.2022-kabul tarihi: 20.02.2022; DOI: 10.29000/rumelide.1074534]

Dr. Öğr. Üyesi, Ankara Hacı Bayram Veli Üniversitesi, Edebiyat Fakültesi, Mütercim ve Tercümanlık Bölümü (Ankara, Türkiye), selminsoylemez@gmail.com, ORCID ID: 0000-0001-7231-7523

Adres $\mid$ Address

RumeliDE Dil ve Edebiyat Araştırmaları Dergisi Osmanağa Mahallesi, Mürver Çiçeği Sokak, No:14/8 Kadıköy - İSTANBUL / TÜRKIYE 34714 e-posta: editor@rumelide.com tel: +90 $5057958124,+902167730616$

RumeliDE Journal of Language and Literature Studies

Osmanağa Mahallesi, Mürver Çiçeği Sokak, No:14/8

Kadıköy - ISTANBUL / TURKEY 34714

e-mail: editor@rumelide.com,

phone: +90 505 7958124, +90 2167730616 


\title{
A norm- and equivalence-based descriptive analysis of the metaphorical expressions in two Turkish translations of ' 1984 ' by George Orwell
}

\begin{abstract}
The main purpose of the study is to analyze two different Turkish translations of the metaphorical expressions in the novel "1984" written by George Orwell in a comparative and descriptive way in the light of Gideon Toury and Eugene A. Nida's Translation Theories. In this context, the study aims to determine how the metaphorical expressions in Orwell's novel are translated to Turkish and Turkish culture by translators. For this purpose, a total of nine text units containing metaphorical expressions have been selected equally from each part of the source text, which consists of three parts, and analyzed within the framework of Toury's Theory of Norms and Nida's Formal and Dynamic Equivalence Theory. In the study, as the source text, the copy of the original text published by Penguin Books in 2008; as the target texts, the first translation of the original text in Turkish, 1958 - V. Turhan and S. Tonguç's translation, and 2010 - Celâl Üster's translation, which is the most popular one among Turkish readers, have been used. The current study has been carried out using the document analysis method, one of the qualitative research methods. When the findings obtained as a result of the study are evaluated, it is understood that the target text translators have adopted two different translation approaches. It is seen that the first target text translators, Turhan and Tonguç, have sometimes remained faithful to the cultural norms in which the source text was created, and sometimes to the norms system of the target language and culture while translating metaphorical expressions. Therefore, it can be said that they have produced both "adequate" and "acceptable" translations in the context of metaphorical translations. In this regard, it can be argued that "formal equivalence" in some cases and "dynamic equivalence" in other cases have been provided between the source text and the translated text. In addition, it can be said that the translators have aimed to create a brief target text since it has been observed that they have resorted to omissions in their metaphorical translations. The second target text translator, Üster, has tended to translate metaphorical expressions by adhering to the norms of the target language and culture. In this respect, it can be argued that he has adopted an "acceptable" translation approach in the translation of metaphorical expressions. In this case, it is an expected result to experience some deviations from the source text. It can be asserted that he has provided "dynamic equivalence" since it is thought that he has aimed to create the same effect on his readers as the source text does on its readers.
\end{abstract}

Keywords: Translation analysis, metaphor translation, cultural norms, formal equivalence, dynamic equivalence

\section{Giriş}

İnsanlık tarihi boyunca farklı medeniyetler, topluluklar ve insanlar arasındaki iletişimin nasıl sağlandığı konusu tartı̧ıldığında her zaman akla ilk yazılı ve sözlü çeviri gelmektedir. Bireyler arasındaki yazılı ve sözlü iletişimi sağlama konusunda hayati derecede önemli bir role sahip olan çeviri faaliyeti gerek bilimsel gerekse dini amaçlar uğruna insanlığın önemli eserlere ulaşmasını mümkün kılmıştır. İnsanlar arasındaki ilk çeviri faaliyetlerinin ne zaman başladığı tam olarak bilinmemesine rağmen akademik bir disiplin olarak çeviri çalışmalarının 20. yüzyılın ilk yarısından sonra ortaya çıkmaya başladığı bir gerçektir. Çeviri çalışmalarını "Çeviribilim" (Translation Studies) adı altında bağımsız bir bilim dalı olarak tüm dünyaya tanıtan ilk Amerikalı çeviribilimci James S. Holmes olmuştur (Munday, 2001: 5).

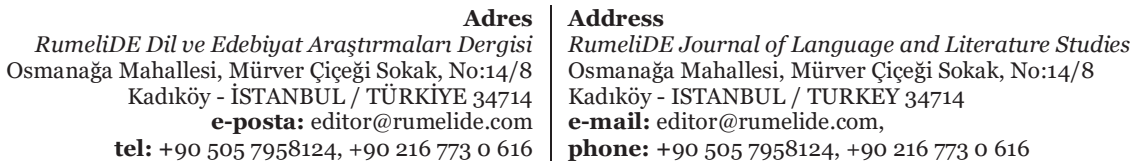


James S. Holmes 1972 yılındaki "Çeviribilimin Adı ve Doğası" (The Name and Nature of Translation Studies) adlı çalışmasında çeviribilimden bilimsel bir disiplin olarak bahsetmiş ve genel hatlarıyla bu disiplinin yapısını, içeriğini ve çerçevesini tanımlamıştır (Toury, 1995: 7). Holmes, çeviri çalışmalarının seyrini değiştiren ve çeviri tarihine çok önemli katkılar sunan bu çalışmasıyla yalnızca çeviriyi dilbilim ve edebiyat gibi bilim dallarından bağımsız bir ihtisas alanı haline getirmekle kalmamış, aynı zamanda bu alanın gelişmesinin ve farklı çeviribilim kuramlarının ortaya çıkışının önünü açmıştır. Ayrıca Holmes (1988: 78) çeviribilim disiplinini betimleyici, kuramsal ve uygulamalı alanlar olarak üç kategoriye ayırarak tanımlamıştır. Holmes'un bu çalışması doğrultusunda çeviribilimci Gideon Toury, çeviribilim gibi disiplinlerin asıl amaçlarının uğraş alanlarındaki olguları betimlemek, açıllamak ve öngörmek olduğunu öne sürmektedir. Ona göre çeviribilim, tabiatı gereği ampirik bir bilim dalı olduğundan kuramsal ve betimsel boyutları arasındaki karşılıklı ilişkiden dolayı daha somut ve kayda değer çalışmaların üretilmesi gerektiğini vurgulamaktadır (1995: 1).

Akademik bir disiplin olarak bağımsızlı̆̆ını yirminci yüzyılın son çeyreğinde kazanan çeviribilim alanında diğer bilim dallarıyla kıyasla mevcut çalışmaların oldukça az olduğu bir gerçektir. İnce (1997) ve Kocabıylk'n (2021: 7) da dile getirdiği gibi bu çalışmalar çeviri kuramları çerçevesinde gerçekleştirilen çeviri analizleri yerine başlı başına çeviri kuramları ve de çeviri edinimi üzerine yoğunlaşmaktadır. Ayrıca var olan bazı çeviri analiz, bir başka ifadeyle çeviri eleştirisi çalışmalarında da çeviribilimsel eğitim almamış veya çeviribilim dışındaki diğer bilim dallarındaki araştırmacılar ya da eleştirmenler genellikle "harika bir çeviri", "çok akıcı" biçiminde çok genel yargılamalarda bulunmakta ve dolayısıyla özgün metinle çeviri kuramları bağlamında bilimsel bir yolla karşılaștırma yapmamaktadırlar. Bu hususta Karantay (1993), bilimsel bir çeviri analiz çalışmasının kesinlikle bir "hata avcılı̆̆ı" olmadığının önemine vurgu yapmaktadır.

Bilimsel bir çeviri eleştirisi gerçekleştirmenin yollarından birisi kaynak metinle erek metnin dizgeli bir şekilde karşlaştırılarak analiz edilmesini içermektedir. Bunu yaparken de yalnızca kaynak ve erek metinler değil, metinlerin ait olduğu dizgeler de göz önünde bulundurulmalıdır. Karşılaştırmalı çeviri analizleri, çeviri metinler erek dilde oluşturulduğunda hangi normların ve de çevirmen tercihlerinin hâkim olduğunu, kaynak metinden çeviriler yapılırken ne kadar sapmaların yaşandığı ve bu sapmaların muhtemel nedenlerini incelemeyi amaçlamaktadır. Bu doğrultuda da çeviri eleştirmenleri çeviri metinlerle ilgili olarak sadece kendi öznel algılarını, sezgilerini ve zevklerini yansıtmaktan kaçınmalıdırlar. Belirli bir çeviri kuramı çerçevesinde çeviri metinleri ve de çeviri sürecini sistematik bir şekilde değerlendirmek, onlar hakkında nesnel çözümlemeler ve öznel fikirler ortaya koymak demektir (Aksoy, 2001: 1-2).

Günümüzde çeviribilim çalışmaları oldukça önem kazanmıştır. Bu da çeviribilimin yeni bir bilim dalı oluşundan ve mevcut çalışmaların azlığından kaynaklanmaktadır. Dolayısıyla kuramsal bir temele dayanan bilimsel bir çeviri analiz çalışmasının çeviribilim alanına çok büyük katkılar sunacağı düşünülmektedir. Ayrıca alanyazın taraması yapıldığında yazarların bilgisi dâhilinde "1984" romanındaki eğretilemeli ifadelerin Türkçe çevirileri üzerine herhangi bir çeviribilim çalışmasının yapılmadığı gözlemlenmiştir. Bu yüzden bu çalışma, 20. yüzyıl İngiliz edebiyatının önde gelen kalemlerinden olan George Orwell'in en önemli eserlerinden biri olan "1984" distopik romanının çevirilerinin karşılaştırmalı bir çözümlemesini ortaya koymaktadır.

Çalışmanın amacı, George Orwell tarafından kaleme alınan "1984" adlı distopik romanda geçen eğretilemeli ifadelerin asıl dili olan İngilizceden Türkçeye farklı çevirmenler tarafından çevrilmiş ve farklı yayınevlerince farklı yıllarda basılmış iki çevirisinin Toury'nin Normlar Kuramı ile Nida'nın Çeviri

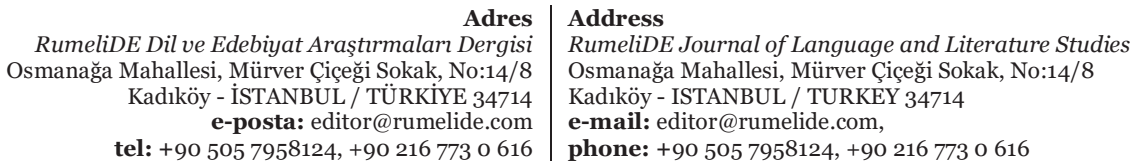


A norm- and equivalence-based descriptive analysis of the metaphorical expressions in two Turkish translations of ' 1984 ' by George Orwell / Z. Sarı \& A. S. Söylemez (pp. 1191-1207)

Kuramı ışığında karşılaştırmalı ve betimleyici bir şekilde incelenmesidir. Bu inceleme sonucunda da çevirmenlerin ürettiği eğretileme çevirilerinin yeterliliği veya kabul edilebilirliğinin sorgulanması amaçlanmaktadır.

Çalışma kapsamında bahsi geçen kaynak metnin 2008 yılında Penguen Kitapları (Penguin Books) yayınevi tarafından basılan nüshasından yararlanılmıştır. Erek metinler olarak da özgün romanın 1958 yılında V. Turhan ve S. Tonguç tarafından yapılan ve Işık Kitapları Yayınevi tarafından basılan çevirisi ile 2010 yılında Celâl Üster tarafından yapılan ve Can Yayınları tarafindan basılan çevirisi tercih edilmiştir. Söz konusu özgün romanın Orwell tarafından kaleme alınıp yayımlandığı 1949 yılından günümüze kadar roman yirmiden fazla çevirmen tarafından Türkçeye çevrilmiştir. Çalışmada bu iki erek metnin seçilmesinin sebebi ise 1958 - V. Turhan ve S. Tonguç çevirisinin romanın Türkçedeki ilk çevirisi olması, 2010 - Celâl Üster çevirisinin ise Kasım 2021'de 75. baskısının yayımlanmasıyla Türk okuyucuları arasında en çok rağbet gören çeviri olmasıdır. Bu iki erek metnin çevrildiği yıllar arasında yaklaşık yarım asırlık bir zaman diliminin olması çeviri analizi bağlamında oldukça zengin bir içerik sunacağının göstergesi sayılabilir.

Araştırmanın örneklemini kaynak metinden seçilen eğretilemeli ifadeler ve bu ifadelerin farklı yıllarda, farklı çevirmenlerce yapılmış; farklı yayınevlerince basılan iki farklı çevirisi oluşturmaktadır. Örneklem olarak eğretilemelerin seçilmesinin sebebi, özgün romanın eğretileme kullanımı açısından oldukça zengin bir içeriğe sahip olmasıdır.

Zoltán Kövecses (2002: 4), “Ĕ̆retileme: Pratik Bir Giriş” (Metaphor: A Practical Introduction) adlı kitabında eğretilemeyi bir kavramsal alanın bir başka kavramsal alan üzerinden bilişsel ve dilbilimsel açıdan anlatılması olarak tanımlamaktadır. Bu bağlamda hayat kavramının yolculuklar üzerinden, tartışmaların savaş, aşkın yine yolculuklar, kuramların binalar, düşüncelerin yiyecekler, sosyal organizasyonların bitkiler, vb. üzerinden anlatılması ve aynı zamanda anlaşılmasını örnek olarak vermektedir. Kövecses, bir kavramın bir başka kavram üzerinden açıklanmasıyla ya da tanımlanmasıyla elde edilen eğretilemelerin bir kavramın anlaşılmasını kolaylaştırdığını ileri sürmektedir. Bu görüşünü de somut bir kavram olan "yolculuk" üzerinden soyut bir kavram olan "hayat” hakkında düşünmenin çok daha kolay olacağı gerçeğiyle desteklemektedir. Kövecses, eğretilemeleri bilişsel işlevlerine, doğasına, karmaşıklığına, vb. göre farklı şekillerde sınıflandırmaktadır fakat bu çalışma kapsamında eğretilemelerin bu sınıflandırmasına yer verilmemiştir.

Lakoff ve Johnson (1980) ise "Beraber Yaşadığımız Eğretilemeler" (Metaphors We Live by) isimli kitaplarında eğretilemeyi düşünce ya da eylemden ziyade sadece bir dil ve sözcük meselesi olarak değil, tam tersine günlük hayatın her aşamasında yalnızca dilde değil aynı zamanda bireyin düşünce ve eylemlerinde de sıklıkla karşılaşılan bir olgu olarak tanımlamaktadırlar. Onlara göre eğretileme, çoğu insanın zihninde canlandığ gibi günlük dilde pek yer verilmeyen bir olgu olarak şiirsel hayal gücünün veya gösterişli ve etkileyici sözlerin dile getirilmesi değildir (4-5). Lakoff ve Johnson, eğretilemeleri "yapısal” (structural), "yönelimsel” (orientational) ve "ontolojik" (ontological) olarak kategorilere ayırmaktadırlar. Bu hususta da çalışmanın örneklemini oluşturan eğretilemelerin farklı kuramcılar tarafından nasıl tanımlandığı açıklanmıştır.

Çalışmanın giriş bölümünün ardından öncelikle analizin kuramsal çerçevesini oluşturan kuramlar ve veri toplama süreci hakkında bilgiler verilmekte, sonrasında yapılmış olan çevirilerin hangi kuramlara örnek teşkil ettiğinin saptanması amacıyla bir çeviri analizi yapılmaktadır. Sonuç olarak da elde edilen bulgular sunulmaktadır.

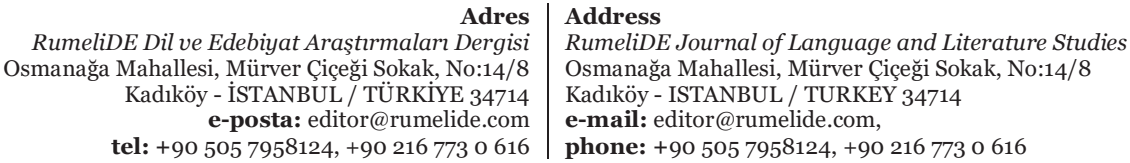




\section{Toury'nin normlar kuramı}

20. yüzyılın son çeyreğinde çeviribilim dünyasına "normlar" kavramını en sistematik, kapsamlı ve çarpıcı bir şekilde kazandıran ilk çeviribilimci Toury'dir. Kendisinden önce Jiri Levy ve James S. Holmes gibi birkaç çeviribilimci çalışmalarında çeviri ile normlar arasındaki ilişkiden bahsetmiş olmalarına rağmen "çeviri normları" (translational norms) kuramını ortaya atan yine Toury olmuştur (Toury, 1998: 11-12). Bu bölümde Toury’nin Normlar Kuramı bütünlük sağlanması açısından tüm alt-boyutlarıyla birlikte açılanmaktadır.

Toury’ye göre "normlar" bireyin sosyalleşmesi esnasında kazanılır ve daima olumlu ya da olumsuz, gerçek ya da olası yaptırımları da doğurmaktadır. Toplumda gerçek davranış biçimlerinin değerlendirilmesi hususunda da bir ölçüt görevi üstlenir. Ayrıca normlar eylemlerin toplumsal geçerliliğine açıllama getirme konusunda da en temel kavramdır ve merkez noktasıdır (1998: 17; 2000: 199-200).

Toury (2012) "Betimleyici Çeviribilim Çalışmaları ve Ötesi" (Descriptive Translation Studies and Beyond) adlı kitabında normlar kuramını "Öncül Normlar", "Süreç Öncesi Çeviri Normları" ve "Çeviri Süreci Normları" şeklinde üç ana başlıkta sinıflandırarak incelemiştir. Öncül Normlar (Initial Norms), çevirmenin çeviri sürecinde benimsediği en genel tavırdır. Bu bağlamda çevirmen ya kaynak metne ve kaynak metnin normlarına sadık kalarak "yeterli" (adequate) bir çeviri ortaya koymayı ya da erek dil ve kültürün ilke ve normlarına bağlı kalarak "kabul edilebilir" (acceptable) bir çeviri oluşturmayı tercih edecektir. Eğer yeterli bir çeviri yaklaşımı benimsenirse erek kültürün norm dizgelerinde birtakım uyumsuzlukların yaşanması büyük ölçüde mümkündür. Eğer çevirmen kabul edilebilir bir çeviri yaklaşımı benimserse de o zaman kaynak metinden bazı kaymaların yaşanması oldukça muhtemeldir $(79-80)$.

Öncül normların ardından Toury (2012: 82) Süreç Öncesi Çeviri Normlarını (Preliminary Norms) "çeviri politikası" ve "çevirinin doğrudanlı̆̆ı" şeklinde birbiriyle bağlantılı iki alt başlı̆̆a ayırarak tanımlamaktadır. Toury çeviri politikasıyla (translation policy) belirli bir zamanda belirli bir dile veya kültüre çeviri aracılığıyla aktarılacak olan metinlerin türlerini ve dahası bu metinlerin teker teker seçimini bile belirleyen faktörleri kastetmektedir. Bu politikanın var olduğundan bu seçimlerin rastgele olmadığı saptandığında söz edilebilir. Ayrıca çevrilecek metinlerin edebi olması ya da olmaması, çevirilerin yazılı olarak mı yoksa sözlü olarak mı yapılacağı, hangi yayınevi tarafından basılacağı gibi farklı alt gruplar da bu kapsamda değerlendirilmektedir.

Toury’ye göre çevirinin doğrudanlığı (directness of translation) çevirinin kaynak dillerin dışındaki ara dillerden de yapılabilmesi karşı duyulan toleransın eşiğini kapsamaktadır. Dolaylı çeviriye yani ara dilden yapılan çeviriye izin verilir mi; çevirinin hangi dillerden, metin türlerinden ve dönemlerden yapılmasına izin verilir ya da yapılması tercih edilir; tercih edilen veya izin verilen ara diller nelerdir; eğer çeviri kaynak metnin asıl dilinden değil de aracı bir dilden yapılmışsa bu gerçek ve hangi aracı dilin olduğu belirtilmeli midir? Çevirinin doğrudanlığı bu tür sorulara cevap aramaktadır (2012: 82).

Çeviri Süreci Normları (Operational Norms) ise çeviri edimi boyunca alınan tüm kararları yönlendirmektedir. Toury (2012: 82) süreç normlarını "Matriks Normları" (Matricial Norms) ve "Metinsel-Dilsel Normlar" (Textual-Linguistic Norms) şeklinde iki alt başlıkta toplamaktadır. Süreç normları hem metnin "matriks"ini yani dilsel malzemelerin erek metinde hangi şekillerde dağıtılacağı hem de metnin nasıl oluş̧turulacağı ve dilsel olarak nasıl ifade edileceğini etkilemektedir. Böylece kaynak

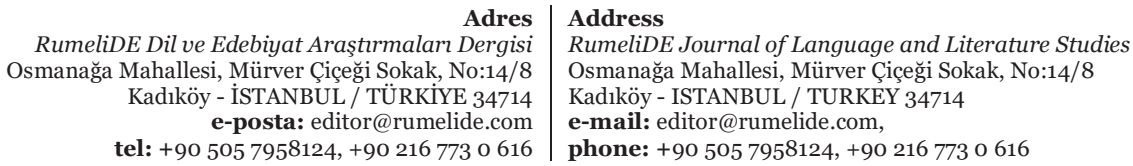


ve erek metinler arasındaki ilişkiyi doğrudan veya dolaylı olarak belirlemektedir. Bir başka ifadeyle çeviri esnasında nelerin değişip nelerin aynı kalacă̆ını yön vermektedir.

Sonuç itibariyle Matriks normlar, kaynak metindeki dilsel malzemeler için tercih edilecek eşdeğer ifadelerin kullanımını denetlemektedir. Ayrıca erek dildeki ifadelerin konumunu ve dağıllsş şeklini; erek metindeki bölümlere ayrılmaları, çıarmaları, eklemeleri, yer değiştirmeleri de belirlemektedir. Metinsel-Dilsel normlar ise erek metindeki dilsel malzemelerin seçimini belirlemektedir. Bu metinseldilsel normlar tüm çeviri metinler için geçerli olabileceği gibi belirli bir çeviri türüne ya da yöntemine de özgü olabilmektedir (Toury, 2012: 82-83).

Çalışmada erek metin çevirmenlerinin Toury'nin Öncül Normlar Kuramı kapsamında kaynak metnin normlarına yakın "yeterli" bir çeviri mi yoksa erek dil ve kültürün normlar dizgesine yakın "kabul edilebilir" bir çeviri mi kayda geçirdikleri incelenmektedir. Çeviri Süreci Normları çerçevesinde de çevirmenlerin benimsedikleri çeviri stratejileri tanımlanmaktadır.

\section{Nida'nın çeviri kuramı}

Amerikalı dilbilimci Eugene A. Nida 1964 yılında yayımladığı "Çeviri Bilimine Doğru" (Towards a Science of Translating) adlı kitabıyla çeviriyi bağımsız bir bilim dalı olarak ilk tanıtanlardan olmuştur (Yazıcı, 2005: 16). Bu bölümde çeviribilim alanına büyük katkılar sunan Nida’nın çeviri kuramı detaylı bir şekilde sunulmaktadır.

Biçimsel ve Devingen Eşdeğerlik kuramı ile İncil Çevirisi Teorisini geliştiren ve modern çeviribilimin kurucularından olan Nida, çeviriye bir iletiyi bir dilden başka bir dile aktarmak şeklinde bilimsel bir tanım getirmekte ve çeviriyi pratik yaptıkça elde edilebilecek bir beceri olarak görmektedir (Nida, 1964: 3).

Nida (1964: 159) gerçekte özdeş eşdeğerlik denen bir şeyin olmadığını düşündüğünden çevirmenlerin çeviri sürecinde mümkün olan en yakın eşdeğer ifadeleri bulmaları gerektiğini dile getirmektedir. $\mathrm{Bu}$ bağlamda da Biçimsel (Formal) ve Devingen (Dynamic) eşdeğerlik adında iki farklı eşdeğerlik türü ortaya koymaktadır. Biçimsel eşdeğerlik hem biçim hem de içerik olarak mesajın kendisine yoğunlaşmaktadır. "Kelimesi kelimesine" ya da "birebir çeviri” olarak da adlandırılan bu yaklaşıma göre kaynak dildeki anlam erek dile mümkün olduğunca yakın yani eşdeğer ifadelerle aktarılmalıdır. Bir başka deyişle çevirmen asıl metnin biçimini göz ardı etmeyerek metnin içeriğini olabildiğince kelimesi kelimesine ve anlamlı bir şekilde yeniden üretmeye çalışır. Bu çeviri yaklaşımı okuyucunun kaynak dil bağlamında bir kişiyle mümkün olduğunca tam özdeşleşmesine ve gelenekleri, düşünce tarzlarını ve ifade araçlarını olabildiğince anlamasına izin vermektedir.

Devingen eşdeğerlik çevirisi ise ifadelerin tam doğallı̆̆ını amaçlamaktadır ve alıcıyı kendi kültürü bağlamında konuyla ilgili davranış biçimleriyle ilişkilendirmeye çalışmaktadır. Daha açık bir ifadeyle bu yaklaşım, alıcının kaynak metindeki mesajı anlaması için kaynak dil bağlamındaki kültürel kalıpları anlamasını dayatmamaktadır (Nida, 1964: 159). Kısaca ifade edilecek olursa Biçimsel Eşdeğerlik kaynak metnin normlarına sadık kalınarak yani "kelimesi kelimesine" (mot a mot) yapılmış çeviridir. Devingen Eşdeğerlik ise kaynak metni erek kültüre yaklaştırarak kaynak metnin kendi okurunda yarattığı etkinin aynısının erek kültür okuyucularında da yaratılması amaçlanarak yapılan çeviridir.

Nida ve Taber (1982) "Çeviri Teorisi ve Uygulaması" (The Theory and Practice of Translation) adlı çalışmalarında eşdeğerlik kavramıyla ilgili hususları ve sorunları ayrıntılı bir şekilde incelemektedirler.

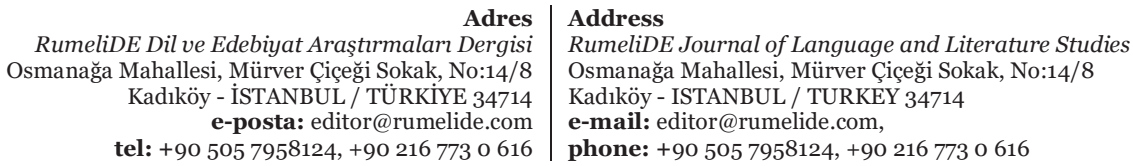


Bu bağlamda eski çeviri uygulamalarındaki odak noktasının mesajın biçimi olduğunu ve eskiden çevirmenlerin ritim, kafiye, kelime oyunları, benzerlik ve olağandışı gramer yapıları gibi kaynak metnin biçimsel özelliklerini yeniden üretebilmeye yoğunlaştıklarını dile getirmektedirler. Fakat yeni yönelimlerle çevirinin odak noktasının mesajın biçiminden alıcının tepkisine evrildiği vurgulanmıştır. Bu çeviribilimcilere göre öncelikle alıcının çeviri metne verdiği tepkinin çevirmenlerce belirlenmesi gerekmektedir. Daha sonrasında ise bu tepki asıl metin okuyucularının kaynak metne vermiş oldukları tepkiyle karşılaştırılmalıdır (1). Nida ve Taber'in bu yaklaşımı Devingen Eşdeğerlik Kuramının temelini oluşturmaktadır. Bir çeviri metin, kaynak metnin kendi okuyucusunda yarattığı etkinin aynısını erek okuyucularda da yaratabiliyorsa işte o zaman devingen eşdeğerlikten söz edilebilmektedir.

Bunun yanı sıra Nida, çeviri eleştirisi bağlamında eskiden sorulan “Bu, doğru bir çeviri midir?" sorusuna “Kimin için?” şeklinde bir başka soruyla cevap vermektedir. Bu cevabıyla da aslında metnin doğru anlaşılmasının önemine vurgu yapmaktadır. Bu bağlamda bir mesajın ortalama bir okuyucu tarafından büyük bir olasılıkla anlaşlabilmesi için değil de aksine herhangi bir kişinin o mesajı çok büyük bir ihtimalle yanlış anlamaması için çevrilmesi gerektiğini ifade etmektedir. Bu sözleriyle de çevrilmiş metnin doğru anlaşılmasından çok yanlış anlaşılmamasının daha önemli olduğunu ve böyle bir çeviri yaklaşımının benimsenmesi gerektiğinin önemine dikkat çekmektedir (Nida ve Taber, 1982: 1; Nida, 1964: 158).

Nida ve Taber'in (1982: 4) çalışmalarında değindikleri bir diğer konu ise biçimin mesajın önemli bir unsuru olmadığı sürece bir dilde söylenebilen bir şeyin başka bir dilde de söylenebileceğidir. Bu görüş Nida'nın Devingen Eşdeğerlik Kuramı kapsamında ortaya atılmıştır. Nida ve Taber'e göre çeviri konusunda en çok tartışılan konu muhtemelen dillerin potansiyel ve gerçek eşdeğerliğidir. Buna açıklık getirmek için de "kar" örneğini vermişlerdir. Hayatlarında karı hiç görmemiş olan insanlara "kar gibi beyaz" ifadesinin nasıl aktarılacağı konusuna kafa yormuşlardır. Bu sorunun cevabının hem karmaşık hem de çeşitli olduğunu fakat burada asıl meselenin bir nesne olarak karın mesaj için o kadar da önemli olmadığını belirtmişlerdir. Bu soruya üç farklı şekilde cevap vermişlerdir: ilki kar kelimesi yerine insanlara aynı şeyi çağrıştıracak başka bir kelimeyle; ikincisi don ya da kırağı gibi kar kelimesiyle eşdeğer bir başka kavramla; sonuncusu da "mantar gibi beyaz" şeklinde eşdeğer bir tabirle ya da "çok, çok beyaz" gibi eğretilemeli olmayan bir ifadeyle aktarmak.

Sonuç itibariyle Nida ve Taber çeviri sürecinin doğasıyla alakalı olarak bir çevirmenin öncelikle mesajı yeniden üretmeyi amaçlaması gerektiğini vurgulamaktadırlar. Onlara göre çevirmen bu amaç doğrultusunda çok sayıda dilbilgisel ve sözcüksel düzenlemeler yapmalıdırlar (1982: 12).

Çalışmada Nida'nın Çeviri Kuramı çerçevesinde erek metin çevirmenlerinin yaptıkları çevirilerde "biçimsel eşdeğerlik" mi yoksa "devingen eşdeğerlik" mi sağladıkları incelenmektedir. Bu bağlamda çevirmenlerin kaynak metnin biçimini göz önüne alarak metnin içeriğini olabildiğince kelimesi kelimesine ve anlamlı bir şekilde aktarmayı mı yoksa kaynak metni erek kültüre yaklaştırarak kaynak metnin kendi okurunda yarattığı etkinin aynısını erek kültür okuyucularında da yaratmayı mı amaçladıkları tespit edilmektedir.

\section{Veri toplama}

Bu çalışmanın örneklemini oluşturan eğretilemeli ifadelerin belirlenmesinde olasıllı temelli örnekleme yöntemlerinden "basit tesadüfi/ rastgele örnekleme yöntemi" benimsenmiştir. Büyüköztürk, Kılıç Çakmak, Akgün, Karadeniz ve Demirel'e (2012) göre bu yöntemde evrendeki bütün birimlerin, bu

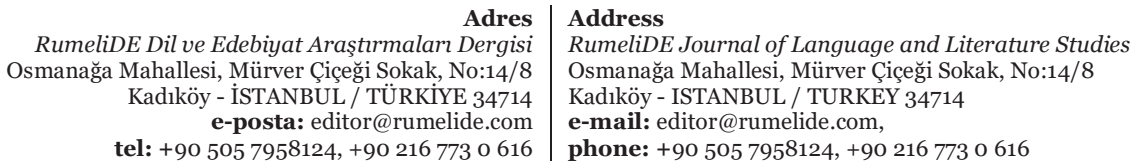


çalışma kapsamında kaynak metindeki tüm eğretilemeli ifadelerin örnekleme seçilme olasılığı eşittir. Böylece metin birimlerinin seçimi birbirini etkilememektedir. Patton'a (2002: 243) göre de bu yöntem örneklemden temsil ettiği evrene genellemeyi mümkün kılmaktadır. Bu bağlamda kaynak metinde teşhis edilen tüm eğretilemeli ifadeler arasından örneklem rastgele seçilmiştir.

Çalışmanın örneklemi olarak seçilen eğretilemeli ifadelerin birer eğretileme olup olmadıklarının kontrol edilmesi için de değerbiçiciler arası güvenirlik sağlanmıştır. Bu konuda alanında uzman iki akademisyenin görüşüne başvurulmuştur. Ardından çalışmanın verileri nitel araştırma yöntemlerinden biri olan doküman incelemesi yöntemiyle elde edilmiştir.

\section{5. "1984" Romanındaki eğretilemeli ifadelerin Türkçe çevirilerinin incelenmesi}

Çalışmanın bu bölümünde söz konusu romandaki eğretilemeli ifadelerin iki farklı Türkçe çevirisi Toury'nin Normlar Kuramı çerçevesinde incelenmekte ve yapılan çevirilerin kaynak metnin normlarına sadık "yeterli" çeviriye mi yoksa erek dil ve kültürün normlarına yakın "kabul edilebilir" çeviriye mi örnek teşkil ettiği açıklanmaktadır. Ardından bu çevirilerin Nida tarafından ortaya atılan Biçimsel ve Devingen Eşdeğerlik kuramından hangisinin özelliğini taşıdığı saptanmaktadır.

Roman üç bölümden oluşmaktadır. Karşılaştırmalı metin çözümlemesi için her bölümden üç adet olmak üzere toplamda dokuz adet eğretilemeli ifadeyi içeren metin birimi rastgele seçilmiştir. Bu şekilde her bölümden eğretileme örneğine yer verilmiştir.

\section{Bölüm 1}

Tablo 1: Metin Çözümlemesi Örnek 1

Kaynak Metin His pen had slid voluptuously over the smooth paper, printing in large neat (KM) capitals- ... over and over again, filling half a page (Orwell, s. 20).

Erek Metin $\quad$ Kalemi, âdeta șehvani bir hazla kaymak kâğıdın üstünde dolașmıș ve hep büyük (EM) 1 harflerle ve sarih olarak şunları yazmıştı: ... (Turhan ve Tonguç, s. 20).

Erek Metin $\quad$ Kalemi pürüzsüz kâğıdın üstünde şehvetle dolaşmış, düzgün büyük harflerle alt (EM) 2 alta yazılmış yazıyla sayfanın yarısı dolmuştu: ... (Üster, s. 42).

Kaynak metnin birinci bölümünde geçen "His pen had slid voluptuously" cümlesinde eğretilemeli bir ifadeye rastlanmaktadır. Bu cümle ilk olarak anlamsal açıdan incelendiğinde cümlenin öznesi olan "pen" kelimesinin "(dolma) kalem", yüklemi konumundaki "slide" fiilinin "kaymak, akıp gitmek" ve yüklemi niteleyen "voluptuously" zarfının da "şehvetli bir şekilde" gibi manalar taşıdığı görülmektedir. Bu cümlenin dilbilgisel açıdan birebir çevirisi "Kalemi pürüzsüz kâğıdın üzerinde şehvetli bir şekilde kaymıştı/ akıp gitmişti” şeklinde olabilmektedir. Bu bağlamda kalem bir eylemi şehvetle, şehvetli bir şekilde gerçekleştirdiğinden bu ifadede "kalem" sözcüğüne insana özgü bir davranış olan kendi isteğiyle ve arzusuyla davranma eylemi atfedilmiştir. Dolayısıyla kalem, kendi isteği ve arzusuyla bir eylemi yapan bir insana benzetilerek kişileştirilmiştir. Kişileştirme söz sanatı da eğretilemeli kullanımın en bariz örneklerinden biridir.

Bu eğretilemeli ifadenin çevirisi için EM 1'in çevirmenleri Turhan ve Tonguç "Kalemi, şehvani bir hazla dolaşmış" ve EM 2'nin çevirmeni Üster “Kalemi şehvetle dolaşmış” biçiminde ifadeler tercih etmişlerdir. Turhan ve Tonguç "voluptuously” zarfi için Arapça kökenli "şehvani" kelimesini kullanmışlardır. Bu erek metnin 1958 yılında basıldığı göz önüne alındığında o zamanlarda Türkçede sıklıkla kullanılan Arapça

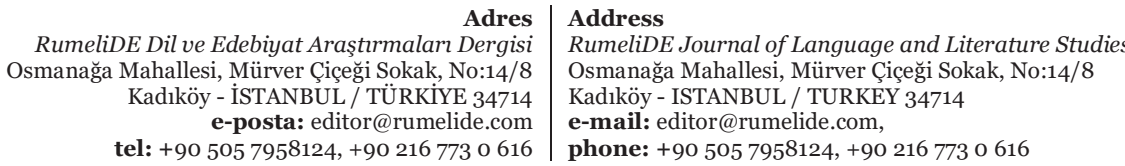


ve Farsça kökenli kelimelerin etkisi bu çeviride hissedilmektedir. Benzer şekilde Üster de bu ifade için Arapça kökenli "şehvani” kelimesinin eş anlamlısı olan Arapça kökenli "şehvetle" kelimesini seçmiştir. Bu hususta her iki erek metin çevirmenleri de kaynak metindeki yapıya ve metnin normlarına tam anlamıyla sadık kalarak bu eğretilemeli ifadeyi birebir çevirmişlerdir. Bu yüzden kaynak metnin normlar dizgesine yakın birer "yeterli" çeviri örneği ortaya konmuştur. Erek metin okuyucusunun bu çevirileri anlamlandırmakta güçlük çekmesi de oldukça muhtemeldir. Bu çeviriler Nida'nın "biçimsel eşdeğerlik" kuramına da örnek teşkil etmektedir.

Tablo 2: Metin Çözümlemesi Örnek 2

KM We're destroying words - scores of them, hundreds of them, every day. We're cutting the
language down to the bone (Orwell, s. 54).
EM 1 Biz kelimeleri yokediyoruz, düzinelercesini, yüzlercesini, hergün Lisanı esash bir
budamaya tâbi tutmaktayzz (Turhan ve Tonguç, s. 49).
EM 2 Sözcükleri yok ediyoruz; her gün onlarcasını, yüzlercesini ortadan kaldırıyoruz. Dili en aza
indiriyoruz (Üster, s. 75).

Kaynak metinde mevcut olan eğretilemeli ifadelerden bir diğeri bu bölümdeki "cutting the language down to the bone" ifadesinde bulunmaktadır. Bu ifadenin yüklemi olan "cut something to the bone" deyiminin Türkçedeki gerçek anlamı "kemiğe kadar kesmek", mecazi anlamı ise "asgari düzeye indirmek, kemerleri sıkmak" şeklindedir. Fiil öbeğini "cut something down" biçiminde ele aldığımızda ise "kesmek, azaltmak, miktarını düşürmek" gibi anlamlarla karşılaşılmaktadır. İfadede dildeki kelimelerin önemli ölçüde azaltıldığından bahsedilmektedir. Bu nedenle burada bir șeyi mümkün olduğunca azaltmak anlamını vermek için kemiğe kadar kesmek şeklinde eğretilemeli bir ifade kullanılmıştır. Bu bağlamda "dil" kavramı kesilebilecek kemikli bir et parçasına benzetilerek aktarılmıştır.

EM 1'in çevirmenleri Turhan ve Tonguç, bu eğretilemeli ifadeyi "Lisanı esaslı bir budamaya tâbi tutmak" şeklinde bir ifadeyle aktarmayı tercih etmişlerdir. Kaynak metinde dil kemikli bir et parçasına benzetilirken bu çevirmenler dili ağaç, çiçek, asma gibi budanabilen bir bitkiye benzeterek aktarmışlardır. Her iki durumda da kesme eylemi gerçekleşmesine rağmen bu çevirmenler kaynak metindeki yapıya bağlı kalmayarak "lisanı budamak" ifadesini kullanmayı tercih etmişler ve böylece erek dil ve kültürün normlarında "kabul edilebilir" bir çeviri örneği sergilemişlerdir. Böylelikle çeviride "devingen eşdeğerliğin" sağlandığı söylenebilir.

Turhan ve Tonguç'un aksine EM 2'nin çevirmeni Üster bu eğretilemeli ifadeyi "Dili en aza indirmek" şeklinde tercüme ederek "cut something down" ifadesini "miktarını azaltmak" anlamıla aktarmıştır. Dolayısıyla çevirmen kaynak metindeki yapıya büyük ölçüde sadık kalarak hem kaynak metnin normlarına "yeterli" uygunluğu hem de "biçimsel eşdeğerliği" sağlamıştır.

Tablo 3: Metin çözümlemesi örnek 3

Some time after their release Winston had actually seen all three of them in the Chestnut Tree Café. He remembered the sort of terrified fascination with which he had watched

KM them out of the corner of his eye. They were men far older than himself, relics of the ancient world, almost the last great figures left over from the heroic days of the Party (Orwell, s. 79).

EM 1 Serbest bırakıldıktan sonra üçünü Winston, Chestunt Tree Café'de görmüştü. İçi korkuyla karışık bir hayranlı dolu, gözünün ucuyla onları seyredişini hatırladı. Kendisinden çok

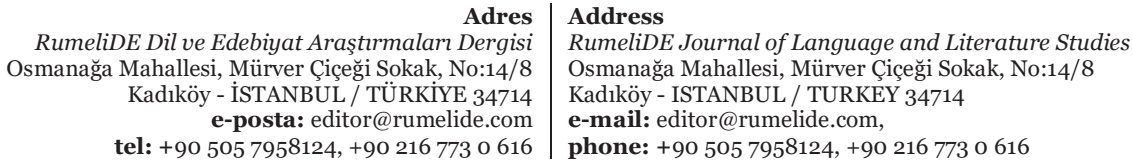


yaşlı adamlardı; eski dünyadan son hâttralar, Partinin ilk kahramanlı günlerine ait son büyük şahsiyetler (Turhan ve Tonguç, s. 73).

Winston, salıverilmelerinden bir süre sonra üçünü de Kestane Ağacı Kahvesi'nde

EM 2 görmüştü. Onlara, gözünün ucuyla hem korku hem de hayranlıkla nasıl baktığını anımsadı. Ondan çok yaşlıydılar, eski dünyanın yadigârları, Parti'nin destansı ilk günlerinin handiyse son büyük temsilcileriydiler (Üster, s. 101).

Birinci bölümde yer alan bir diğer eğretilemeli ifadeye bu örnekteki "relics of the ancient world" isim tamlamasında karşılaşılmaktadır. Bu tamlamanın tamlayanı olan "ancient world" ifadesinin Türkçedeki karşıllğı "antik dünya”, tamlananı olan "relics” kelimesinin karşılı̆̆ ise "eski eserler, kalıntılar, kutsal emanetler" şeklindedir. Bu ifadenin dilbilgisel olarak Türkçedeki birebir çevirilerinden biri "antik dünyanın kalıntıları" biçiminde olabilir. Burada Jones, Aaronson ve Rutherford adlarında Devrim'in üç günahkâr ve yenik lideri geçmişten kalan kalıntılarla ilişkilendirilmektedir. Ayrıca "kutsal emanetler" anlamına da gelen "relics" kelimesinin dini bir çağrışımı da vardır. Bu nedenle bahsi geçen kişiler kutsal olma fikriyle de bağdaştırılmaktadır. Bir başka deyişle kutsal bir varlık olarak da tanımlanmaktadırlar. Dolayısıyla eğretileme kullanımı açısından oldukça zengin bir içeriğe sahip olan bu ifadede ilgili kişiler hem geçmişten kalan kalıntılara hem de kutsal varlıklara benzetilmektedir. Bu da eğretilemeli ifadelere bir örnek teşkil etmektedir.

"Antik dünyanın kalıntıları" şeklinde birebir çevrilebilecek bu eğretilemeli ifadeyi erek metin çevirmenleri sırasıyla "eski dünyadan son hâtıralar" ve "eski dünyanın yadigârları" biçiminde yorumlayarak çevirmişlerdir. Çevirmenler kaynak metinde bulunan ilgili eğretilemeyi kaynak metinde kullanıldığı şekliyle, olduğu gibi erek metinlerine aktarmamışlardır. Erek dil ve kültürün normlarına yakın, erek okuyucuların rahatlıkla anlayabileceği bu ifadelerin "kabul edilebilir" çevirinin birer örneği olduğu söylenebilir. Bu açıdan değerlendirildiğinde bu çevirilerde "devingen eşdeğerliğin" sağlandığı da ifade edilebilir.

\section{Bölüm 2}

Tablo 4: Metin Çözümlemesi Örnek 4

'I didn't want to say anything in the lane,' she went on, 'in case there's a mike hidden there.

KM I don't suppose there is, but there could be. There's always the chance of one of those swine recognizing your voice. We're all right here' (Orwell, s. 125).

"Patikada bir şey söylemedim, belki etrafta bir mikrofon gizlenmiştir diye. Olduğunu

EM 1 sanmiyorum ama, olabilir. Bakarsin o namussuzlardan biri de sesini tanıyıverir. Burada emniyetteyiz." dedi (Turhan ve Tonguç, s. 110-111).

"Patikada yürürken, gizli bir mikrofon falan olabilir diye konuşmak istemedim," dedi kız.

EM 2 "Sanmiyorum ama, belli de olmaz. Neme lazım, ya o soysuzlardan biri sesimizi tanırsa. Neyse, burada güvende sayılırız" (Üster, s. 147).

Kaynak metnin ikinci bölümünde karşılaştırmalı ve betimleyici bir şekilde çözümlenmek için ilk olarak bu cümledeki "one of those swine" eğretilemeli ifadesi seçilmiştir. Bu ifadede geçen "swine" kelimesi Türkçede gerçek anlamıyla "domuz", mecazi ve yan anlamıyla ise "hınzır" şeklinde kullanılmaktadır. Bu ifadenin geçtiği cümlenin Türkçedeki birebir çevirisi "O domuzlardan birinin sesinizi tanıma şansı her zaman vardır” şeklinde olabilmektedir. Aslında burada domuzlarla kastedilen Parti’nin ajanlarıdır. Son derece nahoş, çirkin, antipatik ve kaba bir adamı tanımlamak için sıkça kullanılan bu eğretilemeli ifadede insanların hayvan formunda yansitıldığı ya da hayvan özelliklerinin insanlara atfedildiği

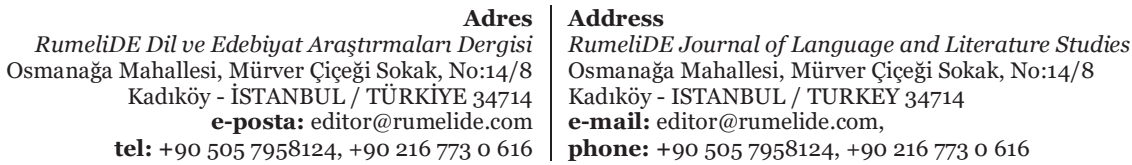


zoomorfizm'den yararlanılmıştır. Antipatik ve kaba bir insanın domuza benzetilerek aktarılmasıyla eğretilemeli bir ifade elde edilmiştir.

EM 1 ve 2'nin çevirmenleri Turhan ve Tonguç ile Üster'in bu eğretilemeli ifade için buldukları Türkçe karşllıklar sırasıyla "o namussuzlardan biri" ve "o soysuzlardan biri” şeklindedir. Kaynak metinde mevcut olan ve insanların domuz formunda yansıtıldığı bu eğretilemeli ifadenin Türk kültüründe aykırı düşebileceği ihtimaline karşı erek metin çevirmenleri ilgili ifadeyi kaynak metnin bağlamına ve semantiğine sadık kalarak Türk dili ve kültürünün normları ile uyumlu bir hale getirmişlerdir. Türk okuyucuların rahatlıkla anlayabileceği ifadelerin tercih edilerek yapıldığı bu çeviriler erek dil ve kültürün normlar dizgesinde "kabul edilebilir" çeviri örnekleridir. Çevirmenlerin kaynak okuyucuda yaratılan etkinin aynısını erek okuyucularda da yaratmaya çalıştıkları düşünüldüğünde bu çeviri yorumlarının "devingen eşdeğerliğe" de örnek teşkil ettiği öne sürülebilir.

Tablo 5: Metin Çözümlemesi Örnek 5

KM Even while he was speaking to O'Brien, when the meaning of the words had sunk in, a chilly shuddering feeling had taken possession of his body (Orwell, s. 166).

EM 1 O'Brien ile konuşurken dahi, sözlerinin mânasını kavradığı vakit vücudunu bir ürperme almıştı (Turhan ve Tonguç, s. 144).

EM 2 O'Brien'la konuşurken bile, sözcüklerin anlamını sezdiğinde, soğuk bir ürperti geçmiști gövdesinden (Üster, s. 189).

Kaynak metnin bu bölümünde yer alan "a chilly shuddering feeling had taken possession of his body" cümlesi eğretilemeli ifade kullanımı açısından oldukça zengin bir içerik sunmaktadır. Bu cümledeki kelimeler anlamsal olarak incelenecek olursa cümlenin öznesi konumundaki "feeling" kelimesinin "duygu, his"; bu kelimeyi niteleyen "chilly" sıfatının "serin, soğuk" ve "shuddering" sıfatının "titreten, ürpertici"; son olarak da cümlenin yüklemi olan "take possession of something" fiil öbeğinin "ele geçirmek, -in sahibi olmak" gibi manalar taşıdığı görülmektedir. Bu açıdan değerlendirildiğinde bu cümlenin dilbilgisel açıdan Türkçedeki birebir çevirisi "soğuk bir titreme hissi vücudunu ele geçirmişti" biçiminde olabilmektedir.

Bu cümlenin öznesi olan "a chilly shuddering feeling" sıfat tamlaması tek başına ele alındığında "his" kavramının soğuk ve titretici sıfatlarıyla tanımlandığı saptanmaktadır. Dolayısıyla "his" kavramı soğuk olan ve insanların titremesine neden olan rüzgâra benzetilmektedir. Yani soyut bir kavram somut bir kavramla ilişkilendirilerek aktarılmıştır. Tekrardan cümlenin tamamına bakılacak olursa rüzgâra benzetilen "his" kavramının insan bedenini ele geçirdiği ya da insan bedenine sahip olduğu anlaşılmaktadır. Bu nedenle burada da "his" kavramı insanı ve insan bedenini ele geçiren bir ruha ya da insana benzetilerek kişileştirilmektedir. "His" kavramının hem rüzgâra hem de insana benzetildiği bu cümle eğretileme kullanımına bir örnek teşkil etmektedir.

EM 1'in çevirmenleri Turhan ve Tonguç bu eğretilemeli cümlenin çevirisini "vücudunu bir ürperme almıştı" şeklinde yapmışlardır. Çevirmenler "ele geçirmek, -in sahibi olmak" gibi anlamlara gelen "take possession of something" fiil öbeğini "almak" şeklinde tercüme ederek kaynak metindeki yapıya ve kaynak metnin normlarına sadık kalmayarak bir çeviri gerçekleştirmişlerdir. Erek okuyucu kitlesinin kolaylıkla anlayabileceği bir ifadenin tercih edilmesiyle erek dil ve kültürün normlarına yakın "kabul edilebilir" bir çeviri örneği ortaya konmuştur. Bu bağlamda "devingen eşdeğerliğin" sağlandığı da söylenebilir. Bunun yanı sıra çevirmenler "soğuk, serin" anlamlarındaki "chilly" sıfatını da çevirmemişlerdir. Bunun sebebi ise "ürperme” sözcüğünün "chilly”yi çağrıştırması olabilir. İfade

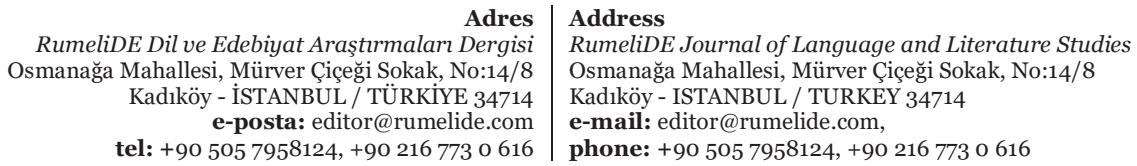


A norm- and equivalence-based descriptive analysis of the metaphorical expressions in two Turkish translations of '1984' by George Orwell / Z. Sarı \& A. S. Söylemez (pp. 1191-1207)

düşürüldüğü için çevirmenlerin metni arındırarak okuyucuların metni daha kolay bir şekilde anlayabilmelerini hedefledikleri savunulabilir.

EM 2'nin çevirmeni Üster ise bahsi geçen cümleyi "soğuk bir ürperti geçmişti gövdesinden" şeklinde tercüme etmiştir. "Soğuk bir ürperti” ifadesiyle kaynak metindeki "his" kavramının rüzgâra benzetildiği eğretilemeli ifadeyi kaynak metindeki şekliyle aktarmıştır. Fakat cümlenin yüklemindeki eğretilemeyi "gövdesinden ürperti geçmişti” şeklinde kaynak metindeki yapıya bağlı kalmadan, erek dil ve kültürün normlarına yakın bir şekilde aktarmıştır. Dolayısıyla "devingen eşdeğerliğin" sağlandığı "kabul edilebilir" bir çeviri meydana getirilmiştir.

Tablo 6: Metin Çözümlemesi Örnek 6
KM
Tirelessly the woman marched to and fro, corking and uncorking herself, singing and falling silent, and pegging out more diapers, and more and yet more (Orwell, s. 228).
EM 1 Kadın aşağıda yorulmaksızın gidip geliyor, ă̆zını mandallarla tıkayıp açııor, şarkı söylüyor, sonra susuyor, ve mütemadiyen çocuk bezleri asıyordu (Turhan ve Tonguç, s. 191).
Kadın bıkıp usanmadan gidip geliyor, mandalları ağzına bir alıp bir çıkarıyor, bir şarkı
EM 2 söylüyor bir susuyor, bitmek bilmeyen çocuk bezlerini ha bire ipe asıp duruyordu (Üster, s. 250-251).

Kaynak metnin bu cümlesinde bulunan "corking and uncorking herself" ifadesinde bir başka eğretilemeli anlatıma rastlanmaktadır. Bu ifadedeki “cork” fiilinin Türkçedeki anlamı "(şişeyi) mantarla tıkamak- kapamak, (bir şeyin) ağzını kapatmak" ve bu fiilin zıt anlamlısı olan "uncork” fiili ise "(şişenin) mantarını çıkarmak veya tıpasını açmak” şeklindedir. Bu cümlede kadının yorulmadan bir o yana bir bu yana yürüdüğünden, bir şarkı söyleyip bir sustuğundan, ardı arkası kesilmeyen çocuk bezlerini durmadan ipe astığından bahsedilmektedir. Bütün bunları yaparken de kadın mandalları ăgzına sokar ve gerektiğinde de ağzından çıkarır. Söz konusu ifadede mandalları ağzına koyup çıkarma eylemi, bir şişenin ağzını mantarla tıkayıp tekrardan mantarını çıkarma eylemiyle ilişkilendirilerek anlatılmıştır. Dolayısıyla somut bir eylem bir başka somut eylem üzerinden yansıtılarak aktarılmıştır. Bu kullanım da eğretilemeli ifadelere bir örnek teşkil etmektedir.

Bu eğretilemeli ifadenin çevirisini EM 1'in çevirmenleri Turhan ve Tonguç “ă̆zını mandallarla tıkayıp açmak" șeklinde yapmışlardır. Çevirmenler "tıkayıp açmak" fiilini kullanmayı tercih ederek "cork" ve "uncork" fiillerini gerçek anlamlarıyla kaynak metindeki yapıya büyük ölçüde sadık kalarak çevirmişlerdir. Böylelikle kaynak metnin normlar dizgesine yakın "yeterli” nitelikte bir çeviri örneği ortaya koymuşlardır. Ayrıca yapılan bu çeviride mesajın biçimine de fazlasıyla önem verildiğinden kaynak metinle erek metin arasında "biçimsel bir eşdeğerliğin" de sağlandığı ileri sürülebilir.

EM 1'in çevirmenlerinin aksine EM 2'nin çevirmeni Üster bu eğretilemeli ifadeye karşllık olarak "mandalları ağzına bir alıp bir çıkarmak" şeklinde bir çeviri yorumu getirmiştir. Üster, kaynak metindeki yapıyı erek dil ve kültürdeki kullanım şekliyle yani "mandalları ağzına almak" ve "mandalları ağzından çıkarmak" biçiminde erek metnine aktarmıştır. Türk okuyucuların rahatlıkla anlayabileceği bir metin olușturma çabası içerisinde olduğu düşünülen bu çevirmen, erek dil ve kültürde "kabul edilebilir" bir çeviri gerçekleştirmiştir. Aynı zamanda bu çeviri “devingen eşdeğerliğin” de bir örneğidir çünkü Üster’in kaynak metindeki eğretilemeli ifadeyi Türkçenin normlarıyla uyumlu hale getirerek kaynak metnin kendi okuyucusunda yarattığı etkinin aynısını erek okuyucularda da yaratmaya çalıştığı savunulabilir.

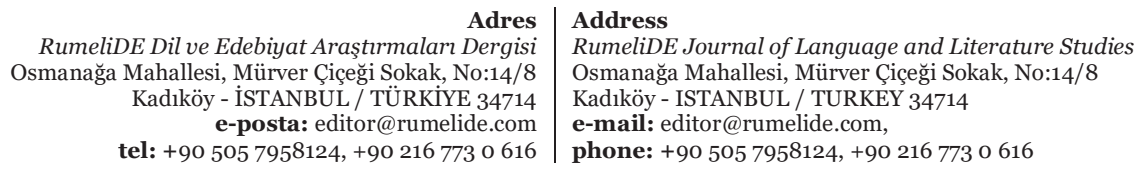




\section{Bölüm 3}

Tablo 7: Metin Çözümlemesi Örnek 7

\begin{tabular}{|c|c|}
\hline $\mathbf{K M}$ & $\begin{array}{l}\text { An enormous wreck of a woman, aged about sixty, with great tumbling breasts and thick } \\
\text { coils of white hair which had come down in her struggles, was carried in, kicking and } \\
\text { shouting, by four guards, who had hold of her one at each corner (Orwell, s. 239). }\end{array}$ \\
\hline EM 1 & ÇEVİRI YOK! (Turhan ve Tonguç, s. 196). \\
\hline EM 2 & $\begin{array}{l}\text { Altmış yaşlarında, koca memeleri karnına sarkmış, ak saçları darmadağınık, harabeye } \\
\text { dönmüș bïr kadın getirmişler, güçbela içeri sokmuşlardı; tekmeler savuran, bağırıp çağıran } \\
\text { kadını dört muhafız zor zapt ediyordu (Üster, s. 261). }\end{array}$ \\
\hline
\end{tabular}

Kaynak metnin üçüncü ve son bölümünden seçilen bu metin birimindeki "an enormous wreck of a woman" isim tamlamasında bir diğer eğretilemeli ifadeye yer verilmiştir. Bu ifadenin tamlayanı olan "woman" kelimesi "kadın, bayan, hanım"; tamlananı olan "wreck" sözcüğ̈̈ "enkaz (gemi), harabe, yıkıntı" ve bu kelimeyi tanımlayan "enormous" sıfatı da "kocaman, muazzam, çok büyük" gibi manalara gelmektedir. Türkçeye "bir kadının dağ gibi/ kocaman enkazı" şeklinde birebir çevrilebilen bu ifade düzensiz, pasaklı ve fiziksel olarak mahvolmuş kadını betimleyen eğretilemeli bir ifadedir. Bir başka anlatımla dağınık ve fiziksel olarak çökmüş bir kadın bir enkaza benzetilerek tasvir edilmektedir. Bu benzetme de eğretilemeli ifadeye bir örnek teşkil etmektedir.

EM 1'in çevirmenleri Turhan ve Tonguç bu eğretilemeli ifadeyi, bu ifadenin bulunduğu paragrafı ve hatta tüm sayfayı atlamışlardır. Bu atlamaları yapmalarının başlıca sebebinin kaynak metni kısa ve öz olarak okuyucularına sunmak olduğu ileri sürülebilir.

EM 1'in çevirmenleri bu eğretilemeli ifadeyi hiç çevirmezlerken EM 2'nin çevirmeni Üster ifadeyi "harabeye dönmüş bir kadın" şeklinde erek metnine aktarmıştır. Bahsi geçen kadının bir harabeye ya da bir enkaza benzetildiği bu eğretilemeli ifade kaynak metindeki şekliyle birebir tercüme edilerek kaynak metinle "biçimsel eşdeğerlik" sağlanmıştır. Fakat aynı zamanda da bu çevirinin erek kültür tarafından "kabul edilebilir" olduğu savunulabilir.

Tablo 8: Metin Çözümlemesi Örnek 8

Behind his screwed-up eyelids a forest of fingers seemed to be moving in a sort of dance, 264).

EM 1 Gözünün önünde parmaklardan mürekkep bir orman dansediyor, kaybolup tekrar ortaya çlkıyordu (Turhan ve Tonguç, s. 215).

EM 2

Sımsıkı kapalı gözkapaklarının gerisinde, bir yığın parmak şıkır şıkır oynuyor, birbirine dolanıp çözülüyor, birbirinin ardında kaybolup yeniden beliriyordu (Üster, s. 286).

Kaynak metnin bu bölümünden yer alan "a forest of fingers seemed to be moving in a sort of dance" cümlesi iki farklı eğretilemeli ifadeyi aynı anda içerisinde barındırdığından oldukça zengin bir anlatıma sahiptir. Bu cümlenin öznesi konumundaki "a forest of fingers" isim tamlaması anlamsal açıdan incelendiğinde tamlamanın tamlayanı olan "finger" kelimesinin "parmak" ve tamlanan olan "forest" sözcüğünün ise "orman" anlamına geldiği görülmektedir. "Bir parmak ormanı" şeklinde Türkçeye birebir aktarılabilecek bu ifadede parmaklar, "bir ağaç ormanı" anlamına gelen "a forest of trees" tamlamasında olduğu şekliyle ağaçlara ya da tamamen bir ağaç ormanına benzetilerek kaynak metin

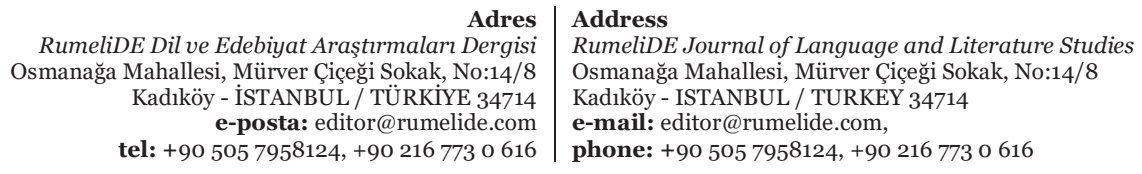


A norm- and equivalence-based descriptive analysis of the metaphorical expressions in two Turkish translations of '1984' by George Orwell / Z. Sarı \& A. S. Söylemez (pp. 1191-1207)

okuyucusuna aktarılmıştır. Bir başka deyişle burada parmaklar, ağaçlardır ya da bir ağaç ormanıdır eğretilemesine ulaşılmaktadır.

Parmakların bir ağaç ormanına benzetildiği “a forest of fingers” tamlamasının yanı sıra ilgili cümlenin "seemed to be moving in a sort of dance" eylem öbeğine bakıldığında burada parmakların dans ediyormuş gibi hareket ettiğinden bahsedildiği anlaşılmaktadır. Dolayısıyla bu cümlede parmaklara ya da eğretilemeli olarak yansıtıldı̆̆ı şekliyle ağaçlara insana özgü bir davranış olan dans etme eylemi atfedildiğinden parmaklar aynı zamanda dans eden bir kişiye benzetilerek kişileştirilmiştir. Sonuç itibariyle kaynak metnin bu cümlesinde parmaklar hem bir ağaç ormanına ya da yalnızca ağaçlara hem de dans eden bir kişiye benzetilerek iki farklı eğretilemeli ifadeden yararlanılmıştır.

EM 1'in çevirmenleri Turhan ve Tonguç, eğretileme kullanımı açısından oldukça zengin olan bu cümleyi "parmaklardan mürekkep bir orman dansediyor" şeklinde Türkçeye aktarmışlardır. Çevirmenler "a forest of fingers" öznesini "parmaklardan mürekkep bir orman” biçiminde çevirerek Türk okuyucusuna pek fazla anlam ifade etmeyen, kaynak metindeki yapıya "parmaklardan ... bir orman” şeklinde tamamen bağlı kalarak fakat "mürekkep (bir orman)" ifadesiyle de bir o kadar kaynak metinden kopuk bir çeviri gerçekleştirmişlerdir. Ayrıca "dansediyor” yüklemiyle de yine kaynak metindeki yapıyı tam anlamıyla koruyarak erek metne aktarmayı seçmişlerdir. Turhan ve Tonguç, böyle bir çeviri yaklaşımını benimseyerek kaynak metnin normlarına "yeterli” uygunluk gösteren ve kaynak metinle "biçimsel olarak eşdeğerlik” sağlayan bir çeviri örneği sergilemişlerdir. Bu tarz bir çeviride erek okuyucu kitlesinin metni anlamlandırmada birtakım güçlükler çekmesi ve erek kültürün uygulamaları ve normlarında bazı uyumsuzlukların yaşanması oldukça muhtemeldir.

EM 2'nin çevirmeni Üster ise bu eğretilemeli ifadenin çevirisini "bir yığın parmak şıkır şıkır oynuyor" şeklinde yorumlayarak erek metnine aktarmayı tercih etmiştir. Çevirmen "a forest of fingers” öznesini "bir yığın parmak” biçiminde aktararak kaynak metindeki yapıya bağlı kalmadan erek okuyucusunun rahatlıkla anlayabileceği bir hale getirmiştir. Bununla birlikte Üster "seemed to be moving in a sort of dance” yüklemini "şıkır şıkır oynamak" deyimiyle aktararak kaynak metinde deyimsel olmayan bir ifadeyi deyimselleştirmiştir. Üster’in böyle bir çeviri yorumu seçmesindeki asıl nedenin kaynak metni erek dil ve kültürün normlarına uygun hale getirme çabası içerisinde olduğu ileri sürülebilir. Böyle bir çeviri yaklaşımı da "devingen eşdeğerliğe" sahip "kabul edilebilir" çeviriye bir örnek teşkil etmektedir.

Tablo 9: Metin çözümlemesi örnek 9

'In your case,' said O’Brien, 'the worst thing in the world happens to be rats.'

A sort of premonitory tremor, a fear of he was not certain what, had passed through Winston

KM as soon as he caught his first glimpse of the cage. But at this moment the meaning of the mask-like attachment in front of it suddenly sank into him. His bowels seemed to turn to water (Orwell, s. 297).

O’Brien: "Senin için dünyada en kötü şey faredir."

EM 1 O anda Winston kutunun önüne takılı maskeye benziyen şeyin neye yaradığını anladı ve çatlak bir sesle haykırdı:

“Olmaz! Yapamazsın! İmkânsız!” (Turhan ve Tonguç, s. 239). ÇEVIRİ YOK!

"Senin durumunda," dedi O'Brien, "dünyanın en kötü şeyinin sıçanlar olduğu anlaşılıyor."

EM 2 Kafesi daha ilk gördüğünde, Winston bir şeyler sezerek ürpermiş, nedenini kestiremediği bir korkuya kapılmıştı. Oysa şimdi kafesin önündeki, maskeye benzeyen eklentinin neye yaradığını birden kavramıștı. Aklı bașından gitti, dizlerinin bağı çözüldü̈ (Üster, s. 320).

\footnotetext{
Adres

RumeliDE Dil ve Edebiyat Araşttrmaları Dergisi Osmanağa Mahallesi, Mürver Çiçeği Sokak, No:14/8 Kadıköy - ISTANBUL / TÜRKIYE 34714 e-posta: editor@rumelide.com tel: +90 $5057958124,+902167730616$

RumeliDE Journal of Language and Literature Studies

Osmanağa Mahallesi, Mürver Çiçeği Sokak, No:14/8

Kadıköy - ISTANBUL / TURKEY 34714

e-mail: editor@rumelide.com,

phone: +90 5057958124, +90 2167730616
} 
Özgün metin yazarı Orwell'in romanında kullandığı bir diğer eğretilemeli ifadeye bu örnekteki "His bowels seemed to turn to water" cümlesinde karşlaşılmaktadır. Bu cümlede geçen "bowel" kelimesi Türkçede "bağırsak, iç kısım” ve "turn to water" eylem öbeği "sulanmak, suya dönmek" gibi anlamlarda kullanılmaktadır. Bu bağlamda bu cümlenin dilbilgisel açıdan birebir çevirilerinden biri "Bağırsakları suya dönmüş gibiydi” şeklinde olabilmektedir. Aslında bu ifadede Winston'ın fare korkusunun etkisi anlatılmak istenmektedir. Bir başka ifadeyle Winston'ın farelerden ne kadar korktuğu, bağırsaklarının suya dönmüş gibi görünmesi üzerinden betimlenmektedir. Bu dil kullanımı da eğretilemeli ifadeye bir örnek sunmaktadır.

EM 1'in çevirmenleri tıpkı Örnek 7'de olduğu gibi kaynak metindeki bahsi geçen eğretilemeli ifadeyi erek metinlerine aktarmamışlardır. Bu cümlenin bulunduğu paragraftaki yalnızca bir cümleyi çevirmişlerdir. Çevirmenlerin bu ifadeyi atlamalarındaki sebebin metni Türk okuyucuların daha basit bir şekilde anlayabilmelerini amaçladıkları olduğu söylenebilir. Bu doğrultuda kaynak metnin kısa ve öz bir şekilde erek okuyuculara aktarılmaya çalışıldığı sonucuna varılmaktadır.

EM 2'nin çevirmeni Üster bu eğretilemeli ifadeyi “Aklı başından gitti, dizlerinin bağı çözüldü” şeklinde yorumlayarak erek metnine yansıtmıştır. Örnek 8'de olduğu gibi kaynak metindeki deyimsel olmayan bir eğretilemeli ifadeyi "aklı başından gitmek" ve "dizlerinin bağı çözülmek" deyimleriyle aktararak deyimselleştirmiştir. Üster'in benimsediği bu çeviri yaklaşımıyla erek okuyucuların rahatlıkla anlayabileceği ve akıcılık düzeyi yüksek bir erek metin ortaya koymayı hedeflediği savunulabilir. Böyle bir çeviri yorumu da erek dil ve kültürün normlarında "kabul edilebilir" bir çeviriye işaret etmektedir. Bütün bu değerlendirmeler sonucunda da kaynak metinle erek metin arasında "devingen eşdeğerliğin" mevcut olduğu söylenebilir.

\section{Sonuç}

Bu çalışmada George Orwell’in "1984" romanındaki eğretilemeli ifadelerin iki farklı Türkçe çevirisi Toury'nin "Normlar Kuramı" ve Nida’nın "Biçimsel ve Devingen Eşdeğerlik Kuramı" çerçevesinde karşılaştırmalı ve betimleyici bir şekilde analiz edilmiştir. Araştırmada öncelikle bir çeviri eleştirisi bir başka deyişle çeviri analizinin bilimsellik özelliği kazanabilmesi için önem verilmesi gereken hususlara değinilmiştir. Ardından çalışmada yararlanılan kuramlar açıklanmış ve son olarak da karşıllaştırmalı çeviri analizi yapılmıştır. Çalışmanın vurgulamaya çalıştığı en temel husus, bilimsel bir çeviri analizinin kuramsal bir çerçeveye oturtulmuş olması gerektiğidir. Aksoy’a (2001: 1-2) göre bilimsel bir çeviri analizi, belirli bir çeviri kuramı ışığında çeviri metinleri ve çeviri sürecini sistematik bir şekilde değerlendirmek, onlar hakkında nesnel çözümlemeler ve öznel fikirler ortaya koymaktır.

Bu çalışmanın sonucunda EM 1'in çevirmenleri Turhan ve Tonguç ile EM 2'nin çevirmeni Üster’in gerçekleştirmiş oldukları çevirilerle ilgili olarak pek çok bulguya ulaşılmıştır. Analizin bütününe bakıldığında erek metin çevirmenlerinin farklı iki çeviri yaklaşımı sergiledikleri görülmektedir. Turhan ve Tonguç, bahsi geçen eğretilemeli ifadeleri kimi zaman kaynak metnin oluşturulduğu kültürel normlara büyük ölçüde sadık kalarak kimi zaman da erek dil ve kültürün normlar dizgesine bağlı kalarak çevirme eğilimi göstermektedirler.

Toury (2012) kaynak metnin normlarına yakın olan çevirileri "yeterli” bir çeviri olarak tanımlamakta ve bu tarz çevirilerde erek okuyucuların pek fazla aşina olmadı̆̆ ve metni anlamlandırmada birtakım güçlükler çekebileceği ifadelerin mevcut olduğundan bahsetmektedir. Ayrıca bu bağlamda erek kültürün uygulamaları ve normlarında bazı uyumsuzlukların yaşanabileceği de dile getirilmektedir. Diğer

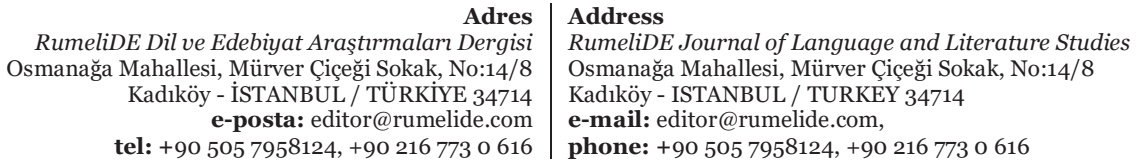


taraftan Toury erek dil ve kültürün normlarına yakın olan çevirileri ise "kabul edilebilir" bir çeviri olarak tanımlamakta ve böyle durumlarda da kaynak metinden birtakım kaymaların yaşanmasının gayet doğal olduğunu ifade etmektedir (79-80).

Ayrıca Turhan ve Tonguç eğretilemeli ifadeleri çevirirken bazı örneklerde kaynak metnin biçimini göz önüne alarak metnin içeriğini olabildiğince kelimesi kelimesine aktarmaya özen gösterdiklerinden Nida'nın (1964: 159) “Biçimsel Eşdeğerlik Kuramına” örnek teşkil eden çeviriler meydana getirmişlerdir. Bazı örneklerde de metnin biçiminden ziyade mesajın kendisine ve erek okuyucuda yarattığı etkiye önem vererek Nida'nın (1964: 159) "Devingen Eșdeğerliğini” sağlayan çeviriler kayda geçirmişlerdir. Son olarak da Matriks Normları bağlamında değerlendirilecek olursa çevirmenlerin kaynak metindeki bazı eğretilemeli ifadeleri atladıkları görülmektedir. Bu atlamaların sebebinin de kısa ve öz bir erek metin oluşturmak olduğu savunulabilir.

EM 2'nin çevirmeni Üster ise söz konusu eğretilemeli ifadeleri genel anlamda erek dil ve kültürün normlar dizgesine yakın bir şekilde erek okuyucularına aktarma eğilimindedir. Kaynak metindeki yapıya pek fazla bağlı kalmadan erek okuyucuların rahatlıkla anlayabileceği ifadeleri tercih ederek çeviriler yapmaktadır. Toury (2012) bu tarz çevirileri "kabul edilebilir" çeviri olarak adlandırmakta ve böyle durumlarda da kaynak metinden birtakım kaymaların yaşanmasının mümkün olduğunu ifade etmektedir (79-80). Üster'in bu çeviri yaklaşımını seçmesindeki asıl sebebin de metnin akıcılık düzeyini arttırmak olduğu öne sürülebilir. Bu bağlamda değerlendirildiğinde de Üster’in kaynak metni erek kültüre yaklaştırarak kaynak metnin kendi okurunda yarattığı etkinin aynısını Türk okuyucularda da yaratmayı hedeflediği söylenebilir. Bu çeviri yorumu da Nida'nın (1964: 159) ortaya attığı "Devingen Eşdeğerliğin" sağlandığının bir göstergesidir.

\section{Kaynakça}

Aksoy, B. (2001). Translation as Rewriting: The Concept and Its Implications on the Emergence of a National Literature. Translation Journal, 5(3). Erişim adresi:

https://translationjournal.net/journal/17turkey.htm

Büyüköztürk, Ş., Kılıç Çakmak, E., Akgün, Ö. E., Karadeniz, Ş., \& Demirel, F. (2018). Eğitimde Bilimsel Araştırma Yöntemleri (25. Baskı). Ankara: Pegem Akademi.

Holmes, J. S. (1988). The Name and Nature of Translation Studies. Translated! Papers on Literary Translation and Translation Studies, 2, 67-80.

İnce, Ü. (1997). Kuram ve Uygulama Bilgisiyle Çeviri Eleștirisi. Hasan Ali Yücel Anma Kitabı/ Çeviri: Ekinler ve Zamanlar Kavşağı içinde. Yıldız Teknik Üniversitesi Yayını, 253-259.

Karantay, S. (1993). Çeviri Eleștirisinin Bilimsel Konumu Üzerine Eleștirel Görüşler ve Bir Model Önerisi. Dilbilim Araştırmaları Dergisi, 4, 17-24.

Kocabıyı, H. S. (2021). Çok Boyutlu Bilimsel Çeviri Eleştirisi Modeli. Ankara: Gazi Kitabevi.

Kövecses, Z. (2002). Metaphor: A Practical Introduction. Oxford University Press.

Lakoff, G., \& Johnson, M. (1980). Metaphors We Live by. The University of Chicago Press.

Munday, J. (2001). Introducing Translation Studies: Theories and Applications. Londra ve New York: Routledge.

Nida, E. A. (1964). Toward a Science of Translating: With Special Reference to Principles and Procedures Involved in Bible Translating. Leiden: E.J. Brill.

Nida, E. A., \& Taber, C. R. (1982). The Theory and Practice of Translation (Vol. 8). Leiden: E.J. Brill.

Orwell, G. (1958). Bin Dokuz Yüz Seksen Dört. Çev. V. Turhan ve S. Tonguç. İstanbul: Iş̧k Kitapları Yayınevi.

\footnotetext{
Adres Address

RumeliDE Dil ve Edebiyat Araştırmalar Dergisi $\quad$ RumeliDE Journal of Language and Literature Studies

Osmanağa Mahallesi, Mürver Çiçeği Sokak, No:14/8 $\quad$ Osmanağa Mahallesi, Mürver Çiçeği Sokak, No:14/8

Kadıköy - İSTANBUL / TÜRKIYE 34714 Kadıköy - ISTANBUL / TURKEY 34714

e-posta: editor@rumelide.com e-mail: editor@rumelide.com,

tel: +90 505 7958124, +902167730616 phone: +90 505 7958124, +90 2167730616
} 
Orwell, G. (2008). Nineteen Eighty-Four. Asıl Baskı. İstanbul: Penguin Books.

Orwell, G. (2010-2021). Bin Dokuz Yüz Seksen Dört. 27-73. Baskılar. Çev. Celâl Üster. Ankara: Can Yaymlart.

Patton, M. Q. (2002). Qualitative Research \& Evaluation Methods (3rd ed.). Sage Publications.

Toury, G. (1995). Descriptive Translation Studies and Beyond. (Vol. 4). Amsterdam ve Philadelphia: John Benjamins Publishing Company.

Toury, G. (1998). A Handful of Paragraphs on 'Translation' and 'Norms'. Current Issues in Language \& Society içinde, 5:1-2, ss. 10-32. Londra ve New York: Routledge. DOI: $10.1080 / 13520529809615501$.

Toury, G. (2000). The Nature and Role of Norms in Translation. Venuti, L. (Ed). The Translation Studies Reader içinde (ss. 198-211). Londra ve New York: Routledge.

Toury, G. (2012). Descriptive Translation Studies and Beyond: Revised Edition (Vol. 100). Amsterdam ve Philadelphia: John Benjamins Publishing Company.

Yazıcı, M. (2005). Çeviribilimin Temel Kavram ve Kuramları. İstanbul: Multilingual Yabancı Dil Yaymlart. 